\title{
Comparative Study of Leaf Surface Texture and Ability to Expand of Cured Tobacco*
}

\author{
by \\ René Robr ${ }^{1}$,Alexandra Eberbard ${ }^{1}$, René Delon ${ }^{2}$, Jean-Pierre Descombes ${ }^{3}$ and Jean-Marie Demor ${ }^{3}$ \\ ${ }^{1}$ Université Claude Bernard Lyon 1, 69622 Villeurbanne, France \\ ${ }^{2}$ Altadis - Institut du Tabac, 24100 Bergerac, France \\ ${ }^{3}$ Altadis - Seita Centre de Recherche, 45404 Fleury les Aubrais, France
}

\section{SUMMARY}

Tobacco leaf texture, appreciated by the difference of surface roughness of cured leaves, is studied with light microscopy and scanning electron microscopy (SEM). The leaf texture is obviously determined by the presence or absence of conical cellular protuberances on the adaxial side of the leaf. Considering the anatomic point of view, the leaf thickness, always more important when the leaf texture is open, is the only objective criterion which could be associated to the texture. The ultrastructural study with SEM and transmission electron microscopy (TEM) demonstrates that the expansion capacity of tobacco doesn't rely on cytological factors such as cellular reserves or debris. The expansion capacity could be inversely proportional with the relative importance of the mesophyll comparing to palisade parenchyma. On the studied material, no direct relation between the leaf texture and the expansion capacity has been noticed. [Beitr. Tabakforsch. Int. 19 (2001) 333-338]

\section{ZUSAMMENFASSUNG}

Die Textur des Tabakblattes, die durch unterschiedliche Rauheit der Oberfläche getrockneter Tabakblätter taktil erfaßt werden kann, wurde mittels Licht-Mikroskopie und Raster-Elektronenmikroskopie (SEM) untersucht. Die Textur wird offensichtlich vom Vorkommen oder Nichtvorkommen kegelförmiger zellulärer Auswüchse auf der Achsenseite des Blattes bestimmt. Vom anatomischen Gesichtspunkt betrachtet ist die Blattdicke, die bei offener Blatt-Textur immer größer ist, das einzige objektive Kriterium, das zur Textur des Blattes in Bezie- hung gebracht werden könnte. Die mittels SEM und Transmissions-Elektronenmikroskopie (TEM) durchgeführten Strukturuntersuchungen zeigen, dass die Expansionsfähigkeit des Tabaks nicht von zytologischen Faktoren wie zellulären Reservestoffen oder Abbauprodukten abhängt. Die Expansionsfähigkeit könnte umgekehrt proportional zur relativen Größe des Mesophylls im Vergleich zum Palisadenparenchym sein. Beim untersuchten Material wurde kein direkter Zusammenhang zwischen der Textur und der Expansionsfähigkeit des Blattes festgestellt. [Beitr. Tabakforsch. Int. 19 (2001) 333-338]

\section{RESUME}

La notion de grain du tabac, apprécié au toucher par la différence de rugosité de surface des feuilles séchées, est étudiée au moyen de la microscopie photonique et électronique à balayage (SEM). Il est montré que le grain est déterminé par la présence ou l'absence de protubérances cellulaires coniques à la surface adaxiale de la feuille. $\mathrm{Du}$ point de vue anatomique, l'épaisseur de la feuille, toujours plus importante lorsque le grain est ouvert, est le seul critère objectif qui puisse lui être associé. L'étude ultrastructurale réalisée aux microscopes électroniques à balayage et à transmission révèle que l'aptitude à l'expansion d'un tabac ne dépend pas de facteurs cytologiques tels que les débris et les réserves cellulaires. L'aptitude à l'expansion pourrait être inversement proportionnelle à l'importance relative du parenchyme lacuneux par rapport au parenchyme palissadique. Sur le matériel étudié, il n'est pas mis en évidence de relation directe entre le grain et l'aptitude à l'expansion. [Beitr. Tabakforsch. Int. 19 (2001) 333-338] 
Table 1.

Relative thickness of dried leaves from tobacco with smooth (V1N1B, V2N1B and BRV-CF3) and rough leaf texture (V1N1A, V2N1A and BRV-XF4) $(p=0.05)$

\begin{tabular}{l|c|c|c|c}
\hline Sample & $\begin{array}{c}\text { Thickness } \\
\text { average }(\mathrm{mm})\end{array}$ & $\begin{array}{c}\text { Standard } \\
\text { variation }\end{array}$ & Variance & $\begin{array}{c}\text { Student } \\
\text { score test }\end{array}$ \\
\hline V1N1A & 0.21 & 0.03 & 0.000886 & 7.098 \\
V1N1B & 0.17 & 0.02 & 0.000487 & significant \\
V2N1A & 0.17 & 0.02 & 0.000654 & 2.643 \\
V2N1B & 0.16 & 0.03 & 0.000789 & significant \\
BRV-XF4 & 0.18 & 0.03 & 0.001081 & 7.007 \\
BRV-CF3 & 0.14 & 0.02 & 0.000664 & significant \\
\hline
\end{tabular}

\section{INTRODUCTION}

It is well known that visual aspects of tobacco leaves are the manifestation of the chemical composition and microscopic structure.

Cured tobacco leaves may have a surface texture that is either (softness) smooth or grainy to the touch. This characteristic, related with leaf quality, varies between varieties and appears to be influenced, for a given variety, by the ontogenetic age of the leaf. As described by TSO (5), many factors are known to affect the physical characteristics. The variety, the stalk position and the stage of development of tobacco plant also might have an influence on the ability of the cured tobacco to rehydrate and to expand, which would be of economic importance in the manufacturing of cigarettes.

It was therefore of interest to understand the basis for the texture of cured leaves, and the ability of cured leaves to expand. These are two physico-chemical properties which don't have an a priori relationship to one another, but both can be studied using similar methodologies based on microscopy techniques.

The main objective of this research is to determine if there is an anatomical relationship between the surface texture of the leaf and its ability to expand. In this study we will provide an anatomical basis to define texture, which, until the present, has been strictly defined by tactile characteristics of the leaf. The anatomical study will be expanded to include characteristics within the leaf that may be linked to the ability of cured leaves to expand.

\section{MATERIAL AND METHODS}

\section{Leaf surface texture}

The range used for the leaf texture study was made of strips of Virginia cured leaves. It included six samples: three of them (V1N1A, V2N1A and BRV-XF4) were known to have a rough surface in relative humidity conditions $(60 \% \mathrm{RH})$, the three others (V1N1B, V2N1B and BRV-CF3) on the contrary were described to have a smooth surface by the touch. One $\mathrm{cm}^{2}$ from 15 strips of each sample was checked for leaf surface study.

Measure of leaf thickness was carried out on dried tobacco leaf fragments with an electronic vernier caliper Digiroch $^{\circledR}$ at $1 / 100 \mathrm{~mm}$. In order to have significant measures, ten thicknesses were randomly determined for each variety (see Table 1) with five samples, corresponding to five different leaves. Measures were taken on leaves kept at $60 \%$ RH.

The leaf texture being discerned by the touch of the adaxial surface of the cured leaf and the study we began with scanning electron microscopy (SEM) on the leaf texture was focused principally on this leaf side.

The samples BRV-XF4 and BRV-CF3 supplied in fragments of cured leaves for a comparative study of the leaf texture, which was very rough for the first one and smooth for the second one, were also available in strips, i.e. scaferlatis (cut tobacco), for the study of expansion ability. These two samples were of particular interest as they allowed us to conduct two parallel studies including: 1) SEM study of the surface of the cured leaf texture, and 2) Structural and ultrastructural studies of cut material for leaf texture and expansion capacity studies.

\section{Environmental scanning electron microscopy}

Scanning electron microscopy (SEM) was used for comparing the surface morphology of tobacco samples $(3,4)$. However the representativity of pictures obtained by SEM depends on whether this technique is suitable for this kind of material. In order to evaluate surface artifacts possibly caused by the sample treatment for the SEM (dehydration, vacuum-coating) specimens without any previous preparation were first observed with the environmental scanning electron microscope (ESEM Electroscan), under $25 \mathrm{kV}$ in moist atmosphere (60-70\% RH) and pictures were taken from precisely identified cell areas. Then, these samples were metallized and the same areas were observed with SEM for comparison.

\section{Scanning electron microscopy}

Cured leaf fragments of 4 to $9 \mathrm{~mm}^{2}$ were sticked adaxial face up on specimen holders, with silver lac (SEM) or double face adhesive tape in the case of specimens observed successively with ESEM and SEM. Those directly studied with SEM were fixed by osmium tetroxide vapours for $1 \mathrm{~h}$, then dehydrated in an oven at $40^{\circ} \mathrm{C}$ for a week before being coated with gold-palladium. This treatment was applied to the others after observation with ESEM. The observations were made on a $S 800$ Hitachi scanning electron microscope under $15 \mathrm{kV}$.

A three-dimensional reconstruction was carried out on a couple of samples chosen for their representativity as far as leaf texture was concerned (BRV-XF4 rough surface and BRV-CF3 smooth surface). Fifteen stereopairs of 


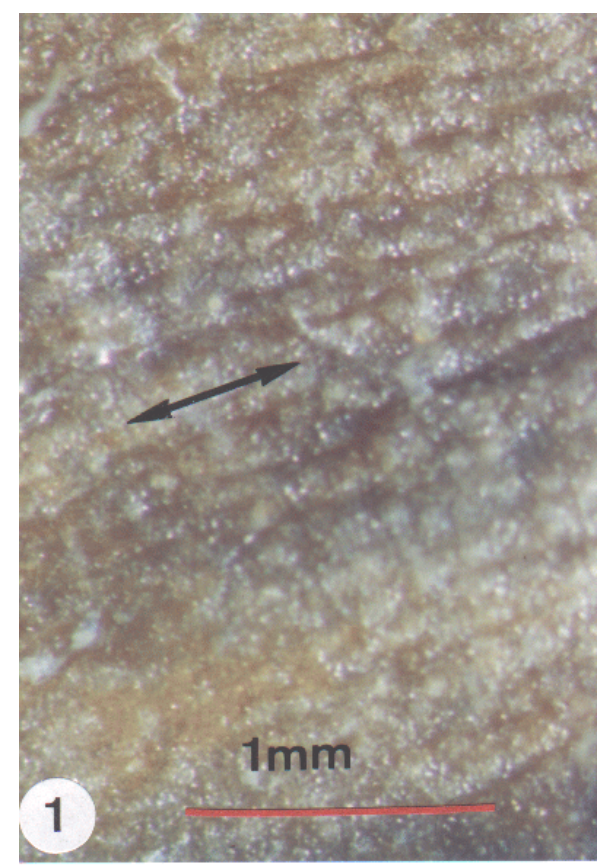

Figure 1.

Upper surface of dried tobacco leaf with smooth texture (V1N1B), RH 60\%

pictures were taken with SEM for each one from the two types, at magnifications comprised from $\times 40$ to $\times 2500$.

\section{Expansion capacity}

The range used for the leaf expansion study was made of four samples, each one consisting of unexpanded and expanded strips of cured leaves, comprising the above mentioned samples. They were chosen according to their low (BSV-MR4, BRV-XF4) or high (BRV-MO2, BRVCF3) expansion ability. Measure of relative thickness of palisade and mesophyll tissues was carried out on semithin cross sections of strips prepared for transmission electron microscopy (TEM). Ten measures were made with each variety before and after expansion.

\section{Transmission electron microscopy}

Samples were fixed in $2 \%$ glutaraldehyde in phosphate buffer ( $\mathrm{pH}$ 7.2) for $1 \mathrm{~h}$ at room temperature. They were postfixed in $2 \%$ osmium tetroxide in veronal buffer $(\mathrm{pH}$ 7.2) for the same time at the same temperature, then block-stained overnight at $4{ }^{\circ} \mathrm{C}$ with aqueous uranyl acetate ( $1 \% v / v$ in veronal buffer). After dehydration in an ethanol series, samples were gradually placed in propylene oxide and embedded in Epon ${ }^{\circledR}$ resin. Thin sections $(75-90 \mathrm{~nm})$ were collected on copper grids and stained for $20 \mathrm{~min}$ in Reynolds' lead citrate. Sections were examined with Philips CM 120 EM at $80 \mathrm{kV}$. Semithin sections $(1 \mu \mathrm{m})$ of the same material were also collected on glass slides and stained with a toluidine blue dye for light microscopy.

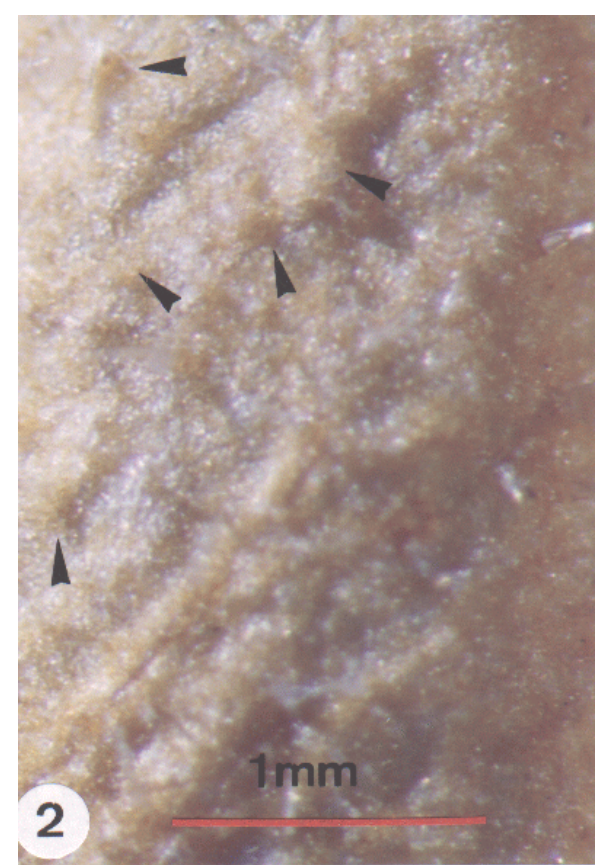

Figure 2.

Upper surface of dried tobacco leaf with rough texture (V1N1A), RH 60\%

\section{RESULTS AND DISCUSSION}

\section{Leaf surface texture}

Studied with stereomicroscope, the surface of V1N1B was even, with epidermal cells aligned along the same axis (Figure 1, arrows). By comparison, the surface of V1N1A was less organized; epidermal cells were covered with high density of papillae (many per millimetre) (Figure 2, arrowheads). The dried leaf of V1N1A had many surface irregularities not found on V1N1B.

No surface modification was noticed on the samples directly observed with ESEM or after treatment for SEM observation. So SEM therefore appeared to be a suitable technique for the surface texture study of cured tobacco leaves.

Stereoscopic imaging provided a method for more precise interpretation of features. Conical projections gave the rough surface of BRV-XF4 leaves a highly varied topography (Figure 3, arrows). The variable size of these structures was due to variable number of cells per projection, which ranged from a few cells to many dozen. Occasionally, the summit of a projection was crowned with a trichome or a stoma. Epidermal cells were frequently encountered that had an expanded, turgescent aspect. It was also noted that some cell walls were highly invaginated, creating crevices among the otherwise flat epidermal surface. In both cases, the external surface of epidermal cells was often clearly folded and concave (Figure 4) or even convex. Sometimes both types were found beside one another. 

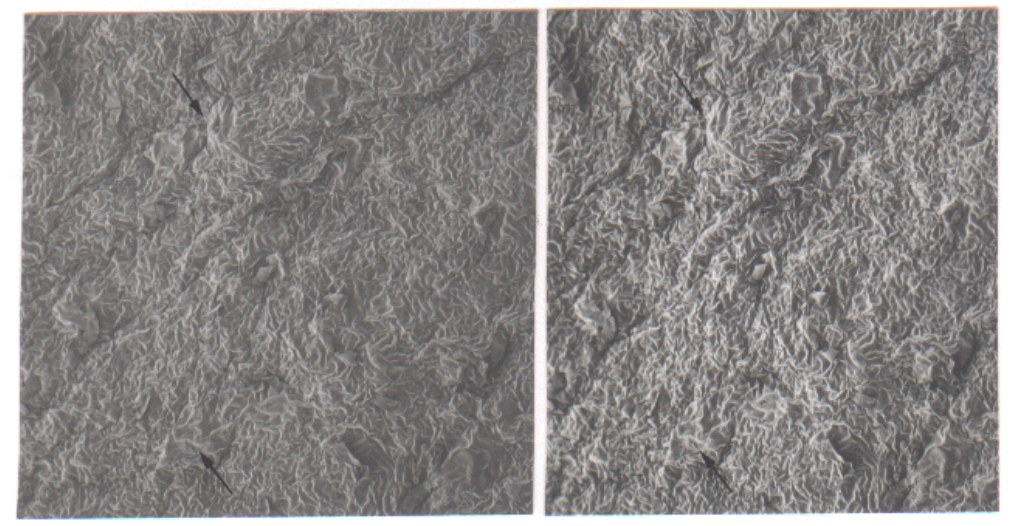

\section{Figure 3.}

SEM stereopair of the upper surface of a tobacco leaf with rough texture (BRV-XF4)
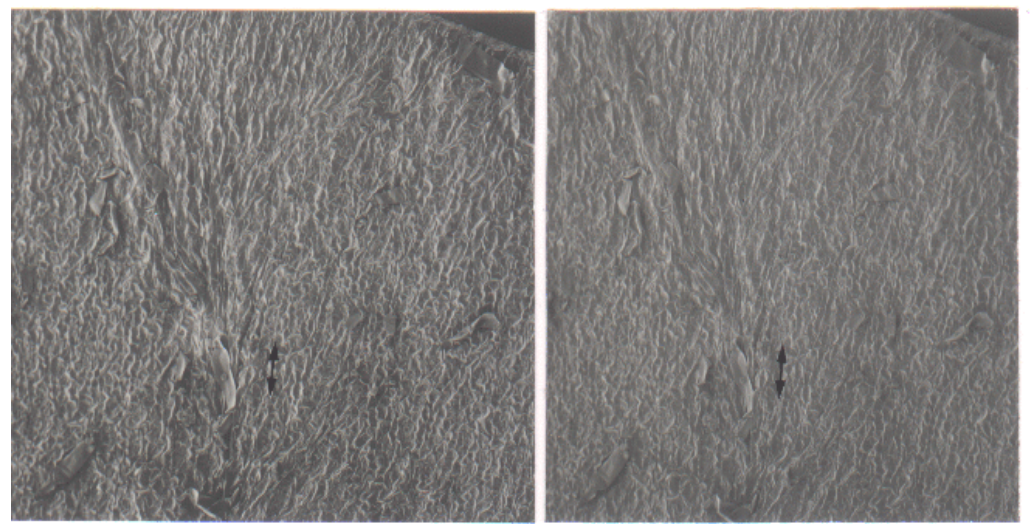

Figure 4.

SEM stereopair of the upper surface of a tobacco leaf with smooth texture (BRV-CF3)

Our stereoscopic images provided further support for observations made in the light microscopic study, that the nature of the surface texture is more closely linked to the arrangement of epidermal cells than the surface features of the cell walls.

The textural characteristic defined, in terms of touch, as rough or smooth, is based on the presence or absence, respectively, of conical epidermal cell projections, which are separated from one another by approximately $0.1 \mathrm{~mm}$.

For all samples, the thickness of the leaves was measured. We have shown that rough leaves V1N1A, V2N1A and $\mathrm{BRV}-\mathrm{XF} 4$, were significantly thicker than smooth leaves of V1N1B, V2N1B and BRV-CF3.

From the tobacco samples studied, it can be concluded that the thickness of leaves with a grainy texture is greater than those of leaves that are smooth.

\section{Aptitude of expansion}

There are internal anatomical differences in cured leaves, depending on whether they are able to expand after rehydration. In leaves that have low capacity for expansion after rehydration, the mesophyll makes up approximately $65 \%$ of the internal area of leaf cross-sections, with the remaining $35 \%$ belonging to the palisade paren- chyma (Figure 5, top left). The mesophyll is 4 to 5 cells in thickness. In contrast, leaves with a high capacity for expansion following rehydration have a 1:1 ratio of palisade to mesophyll (Figure 5, top right) and they have a mesophyll layer of 5 to 6 cells in thickness.

After expansion, the relative amounts of palisade and mesophyll are the same in both types of tobacco, with $61 \%$ of the internal cells being of the mesophyll type and $39 \%$ palisade (Figure 5, bottom). As a consequence, it is possible to distinguish the leaves with a high capacity for expansion following rehydration, as these are the ones with thinner mesophyll.

Although tobacco varieties differ in their ability to expand, they may have similar morphological features. BRV-XF4 and BSV-MR4 have little capacity to expand, BRV-CF3 and BRV-MO2 have a high capacity to expand, yet all of these varieties have a similar leaf anatomy, with the cell contents exhibiting great uniformity, e.g., cytoplasmic debris or reserves. The amount of mesophyll parenchyma would appear to be the most important criterion for leaf expansion, as the amount of intercellular space in the mesophyll appears to be greater in varieties with a high capacity for expansion.

Figure 6 shows that cell walls diminish in thickness following expansion, as is the case with a poorly expanding 


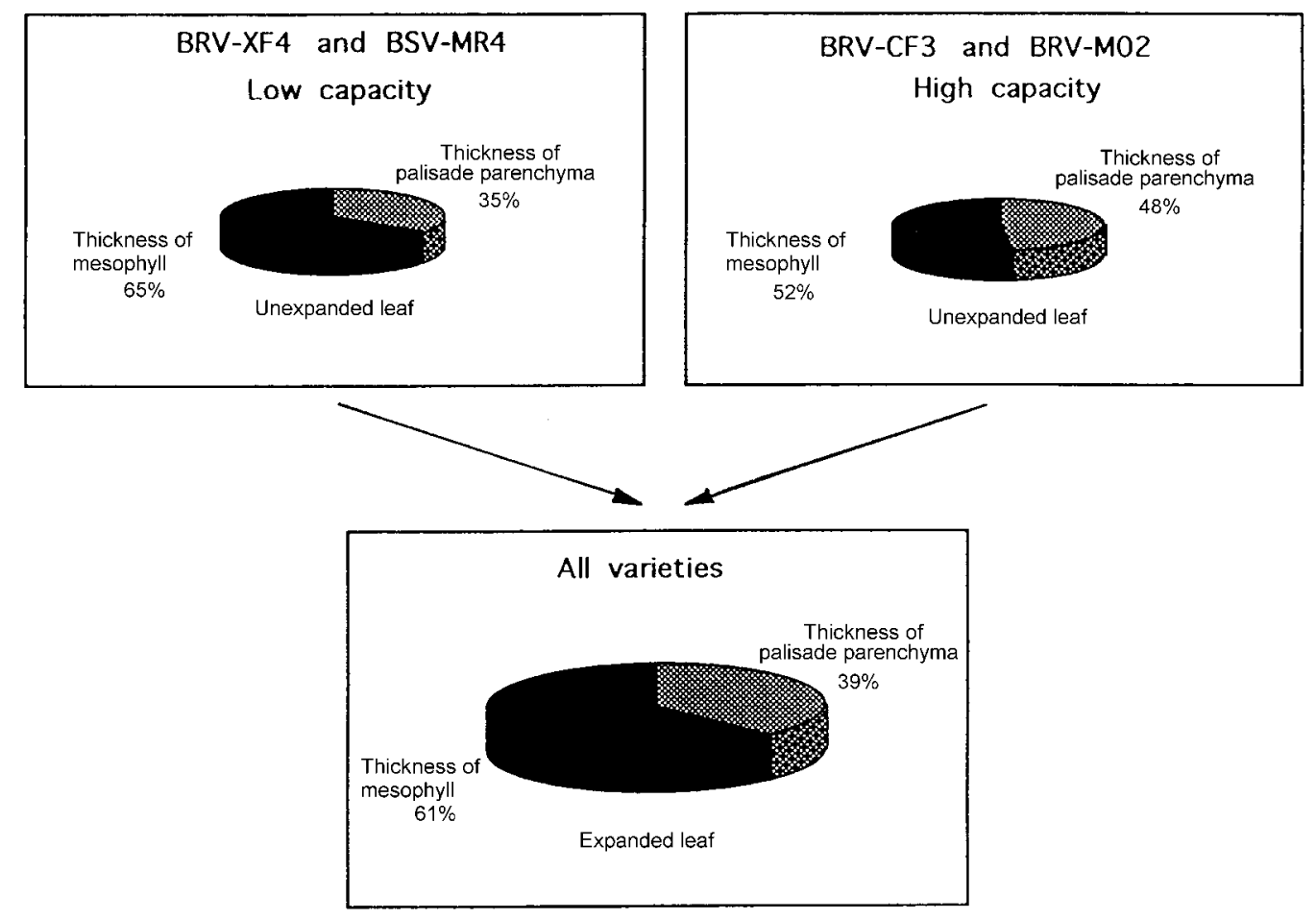

Figure 5.

Relative importance of palisade and mesophyll parenchyma before and after expansion in tobacco varieties with different abilities to expand (measurements were carried out on semi-thin sections)
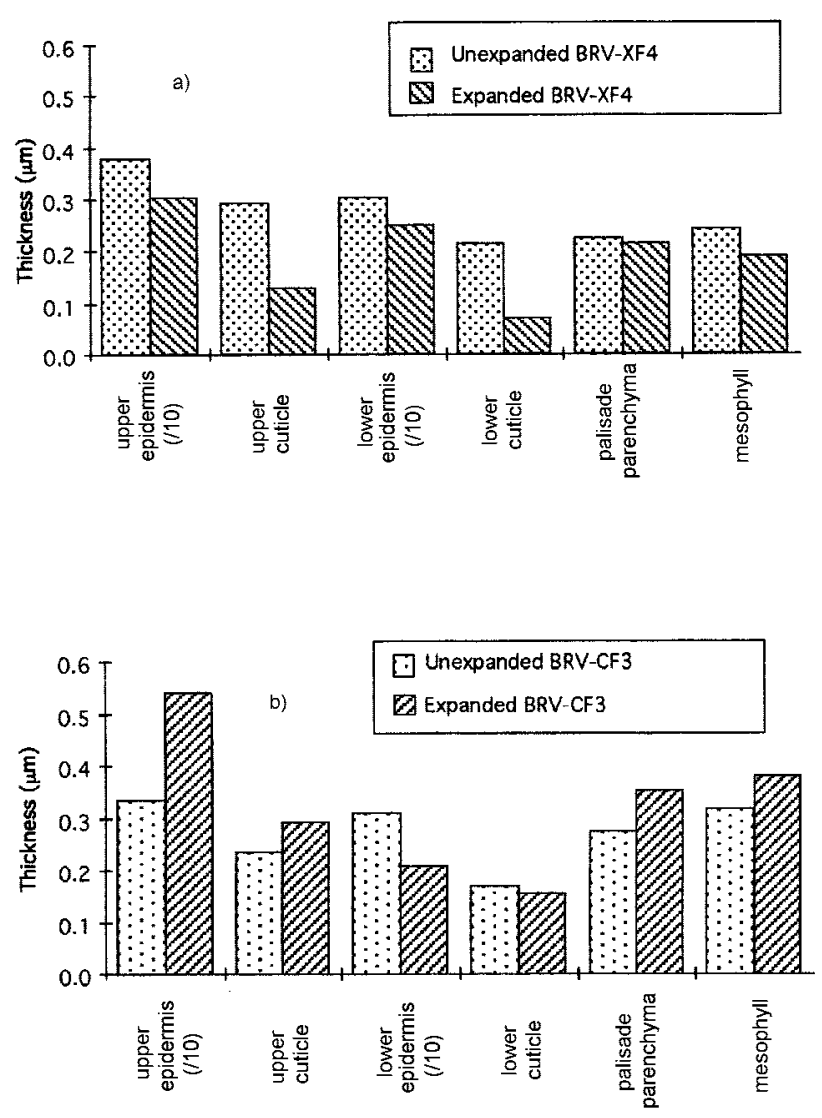

Figure 6.

Thickness of cuticles and cell walls from different tissues before and after leaf expansion; a) tobacco with low expansion ability, b) tobacco with high expansion ability variety, BRV-XF4. This is not the case in varieties with a high capacity for expansion following rehydration, such as BRV-CF3. Wall thicknesses in the latter varieties are greater, especially for the walls of highly expanded cells, such as those of the upper epidermis.

The primary cell wall of leaves that are ontogenetically mature may be more rigid and less able to expand than that of younger leaves. The structure of microfibrils in the cell wall of upper epidermal cells of BRV-CF3 is indicative of loosening (Figure 7), with apparent disassociation of microfibrils accompanied, on occasion, by disassociation of the cuticle itself (Figure 8). This phenomenon was neither observed in desiccated leaves, nor in rehydrated leaves of tobacco varieties with a limited capacity for expansion (Figure 9). Loosening of epidermal cell walls of tobacco had been attributed to the type of fixatives (2), but the fixatives that we used do not have this effect.

Once again, it is important to point out that the quantitative data, which although by their nature and number do not constitute a balanced statistical survey, nevertheless, do not provide evidence of differences in cell wall thickness among the varieties of tobacco tested in this study. We need to corroborate these results with a TEM study of fresh material. This would provide stronger evidence for a possible inverse relationship between the capacity for expansion and the age of the leaf. Moreover, commercially cut tobacco does not lend itself well to such a study as it is not possible to know precisely from which part of the leaf the sample has been taken as the anatomy and thickness of a single leaf can vary throughout the leaf (1). 


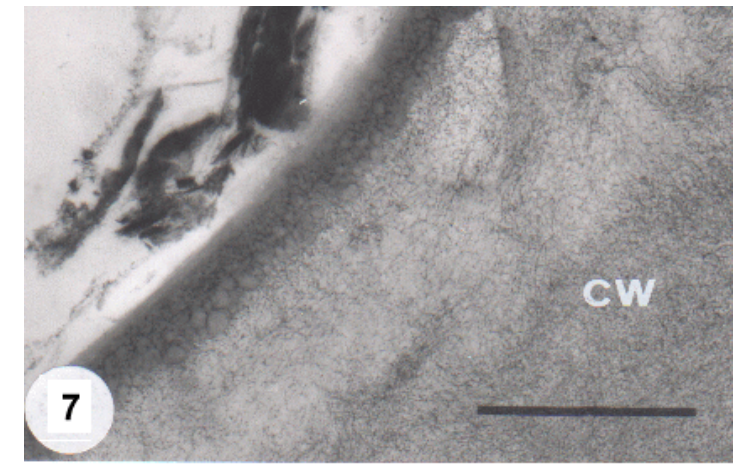

Figure 7.

Upper epidermal cell wall of BRV-CF3 expanded tobacco leaf (scale bar $=1 \mu \mathrm{m} ; \mathrm{cW}=$ cell wall)

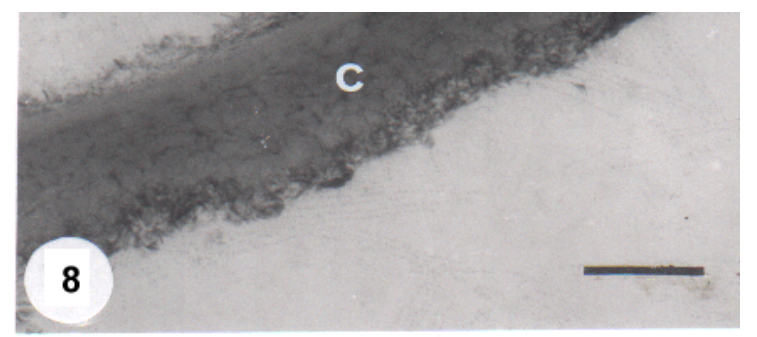

Figure 8.

Upper cuticle of epidermal cell of BRV-CF3 expanded

tobacco leaf (scale bar $=0.2 \mu \mathrm{m} ; \mathrm{c}=$ cuticle)

The cells of tobacco leaves with poor capacity for expansion following rehydration have thicker cell walls than tobacco leaves with high capacity for expansion following rehydration. It is not surprising that in comparison to younger leaves, older leaves are the thickest and possess the most stable cell wall structure.

\section{CONCLUSION}

Using two additional approaches - light microscopy and SEM - we have been able to define the morphological basis of surface texture in tobacco leaves.

Different textures are the result of different arrangements of upper epidermal cells. We propose the following definition of texture: it is the ability to feel the presence or absence of the groups of conical projections found on the upper epidermis. Finally, the only anatomical feature that can be associated with foliar leaf texture is the thickness of the leaf, which is always less in the leaves with a smooth surface.

Based on our observations, the capacity to expand is not influenced by cytological factors such as cell contents. An anatomical difference of importance is the thickness of the mesophyll layer. In varieties with a high capacity for expansion following rehydration there are greater amounts of intercellular space, and subsequently there is a greater ability to expand. As a consequence, we have noticed that the mesophyll of tobacco with a high expansion capacity is thinner and has therefore a higher potential to thicken during expansion process.

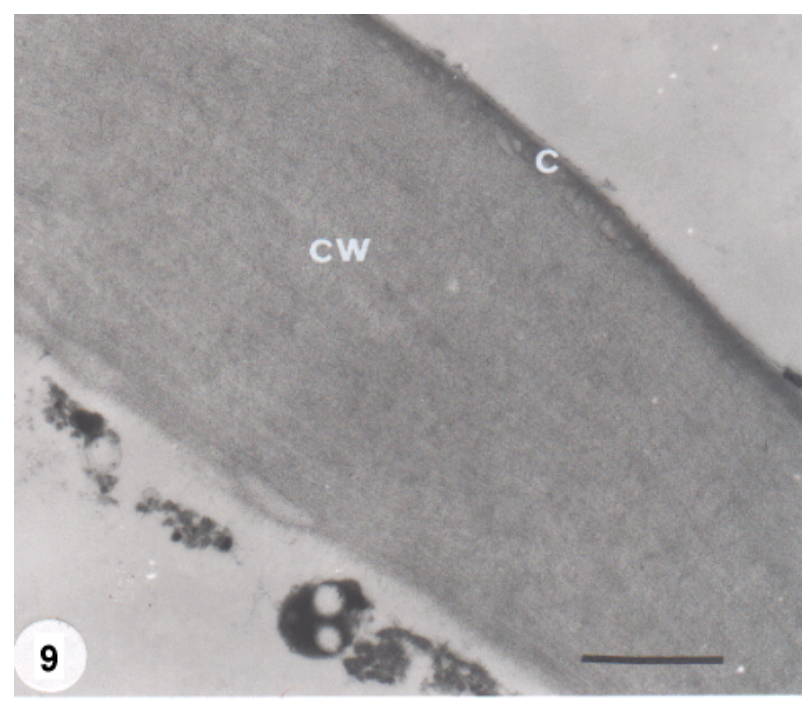

Figure 9.

Upper epidermal cell wall of BRV-XF4 expanded tobacco leaf $($ scale bar $=1 \mu \mathrm{m})$

The other hypothesis that we have advanced is that the ability to expand is inversely related to foliar maturity. The different thicknesses of upper epidermal cell walls in leaves of differing ages should be verified with better defined material.

To get an overall understanding of the phenomenon of expansion and foliar response to expansion, it is recommended that the same samples be tested before and after expansion, as this eliminates variation.

Acknowledgements: The authors thank C.Girard, Tobacco Institute of Bergerac, to have provided the samples of tobacco leaves V1N1 A \& B and V2N1 A \& B very useful for this study. Electron microscopy was carried out at the electron microscope unit of the University of Lyon 1, France (CMEABG).

\section{REFERENCES}

1. Akimoto, Y.: Scanning electron microscopy observation on the internal structure of cured tobacco leaves; Spec. Bull. Leaf Tob. Res. Lab. (1993) 203-212.

2. Krüger, H., L. van Rensburg and J. Peacock: Cuticular membrane fine structure of Nicotiana tabacum L. leaves; Ann. Bot. 77 (1996) 11-16.

3. Mohapatra, S.C. and W.H. Johnson: Microscopic studies of bright leaf tobacco. II; Freeze drying after curing; Tob. Sci. 17 (1973) 33-36.

4. Pitié, B.: Une méthode de détermination du taux de tabac expansé; Ann. du Tabac Sect. I, 15 (1977) 46-53.

5. Tso, T.C.: Production, physiology and biochemistry of the tobacco plant; Ideals, Inc., Beltsville, MD, 1990.

Address for correspondence:

University de Lyon 1

UMR 5557 Ecologie Microbienne, bâtiment Lwoff, 69622 Villeurbanne Cedex, France 